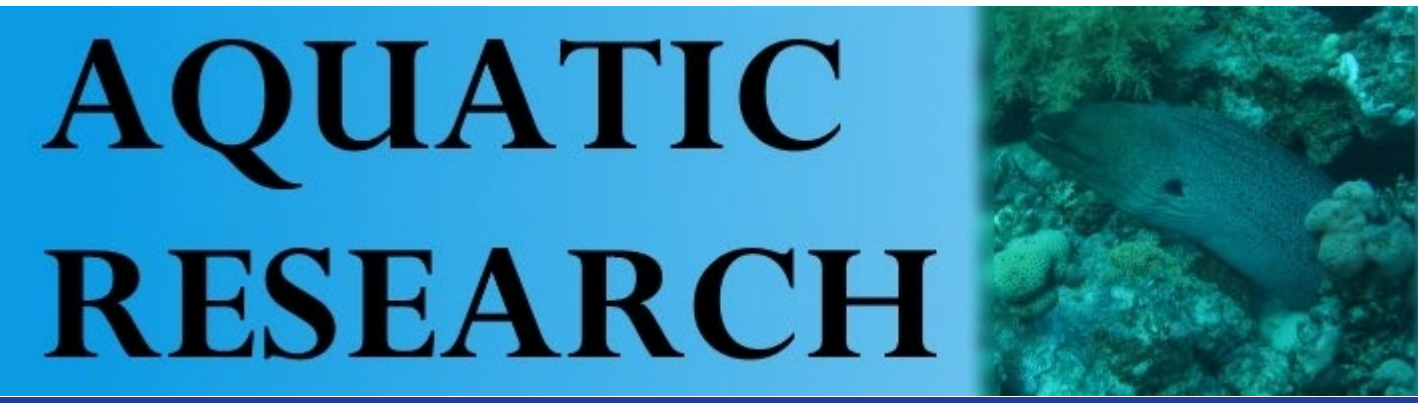

\title{
A NEW LOCALITY FOR THE ENDEMIC Gobio sakaryaensis TURAN, EKMEKÇİ, LUSKOVA \& MENDEL, 2012 IN THE MARMARA REGION (TURKEY) AND THE LENGTH-WEIGHT RELATIONSHIP OF THE SPECIES
}

\author{
Gülşah Saç ${ }^{1}$ (D), Özcan Gaygusuz ${ }^{1}$ (D), Çiğdem Gürsoy Gaygusuz ${ }^{2}$ (D), Müfit Özuluğ $\breve{g}^{3}$ \\ Cite this article as: \\ Saç, G., Gaygusuz, Ö., Gürsoy Gaygusuz, Ç., Özuluğ, M. (2019). A new locality for the endemic Gobio sakaryaensis Turan, Ekmekçi, Luskova \& Mendel, \\ 2012 in the Marmara region (Turkey) and the length-weight relationship of the species. Aquatic Research, 2(1), 36-40. https://doi.org/10.3153/AR19005
}

\begin{abstract}
${ }^{1}$ Istanbul University, Faculty of Aquatic Sciences, Department of Marine and Freshwater Resources Management, 34134, Laleli, İstanbul, Turkey

2 Trakya University, Keşan Vocational High School, 22800 , Keşan, Edirne, Turkey

ABSTRACT

One of the endemic freshwater fish species of Turkey, Gobio sakaryaensis Turan, Ekmekçi, Luskova \& Mendel, 2012 is reported for the first time from the Lake Sapanca Basin. A total of $18 \mathrm{G}$. sakaryaensis specimens was captured using electroshocker on October 18, 2008 and February 5, 2009 from the Maşukiye Stream (western Lake Sapanca). This finding has increased the number of the fish species living in the basin. The value of parameter $b$ in the LWR equation was calculated 3.176 .
\end{abstract}

${ }^{3}$ Istanbul University, Faculty of Science, Department of Biology, 34134, Vezneciler, Istanbul, Turkey

Submitted: 03.01.2019

Accepted: 25.01.2019

Published online: 28.01.2019

Correspondence:

Gülşah SAÇ

E-mail: gulsahsac@gmail.com

๑Copyright 2019 by ScientificWebJournals

Available online at

http://aquatres.scientificwebjournals.com
Keywords: Lake Sapanca, Freshwater fish, Stream, Endemism, New record 


\section{Introduction}

The last comprehensive checklist of the freshwater fishes of Turkey has reported that a total of 409 fish species inhabit in the freshwater systems and 194 of them is endemic to Anatolia (Çiçek et al., 2018). The genus, Gobio is known to be one of the richest genera because of its adaptations to different habitats (Turan et al., 2016). Recently, a total of 14 species belonging to the genus Gobio was recognised from Turkish inland waters, and except Gobio bulgaricus and Gobio kovatschevi all of these species are the Anatolian endemics (Naseka et al., 2006; Kottelat and Freyhof, 2007; Turan et al., 2012; Turan et al., 2016; Turan et al., 2017; Turan et al., 2018). Gobio sakaryaensis is one of the endemic gudgeons and it was described from the Tozman and Porsuk streams in the Sakarya River drainage (northwestern Anatolia, Black Sea basin) (Turan et al., 2012).

One of the most important lakes in the Marmara region of northwest Turkey, the Lake Sapanca is used for fisheries, recreation and potable water resource (Albay et al., 2003). The lake is fed by numerous streams (e.g. Maşukiye, Yanık, Mahmudiye, Kurtköy, İstanbul, Liman, Sarp, Arifiye, Maden) and it has one outflowing river (Çark Stream) connected to Sakarya River (Ercan et al., 2013). The Lake Sapanca and its streams have a rich fish diversity and a total of 27 fish species has been reported from the lake basin (Özuluğ et al., 2007; Tarkan et al., 2007; Tarkan et al., 2008; Okgerman and Altuğ, 2008). This study aims to report the unrecorded fish species, G. sakaryaensis for the Lake Sapanca Basin and provide its length-weight relationship.

\section{Material and Methods}

The routine ichthyological surveys of the Lake Sapanca Basin between 2008 and 2009 were conducted using a portable SAMUS 750-MP electroshocker. The Maşukiye Stream where G. sakaryaensis specimens were collected is flowing from the westward of the lake (Figure 1). The fish samples were killed immediately upon capture with an overdose clove oil and they fixed in 5\% formaldehyde solution.

Measurements were made point-to-point with calipers and recorded to $0.1 \mathrm{~mm}$. Meristic counts were made under a binocular microscope. Methods for counts and measurements follow Kottelat and Freyhof (2007). Standard length (SL) was measured from anteriormost point of the head to the end of the hypural complex. The length of the caudal peduncle is measured from behind the base of the last anal-fin ray to the end of the hypural complex, at mid-height of the caudalfin base. Lateral line scales are counted from the anteriormost scale (the first one to touch the shoulder girdle) to the last scale at the end of the hypural complex. The last two branched rays articulating on a single pterygiophore in the dorsal and anal fins are noted as " $1 \frac{1}{2}$ ". Scales on the caudal fin itself are indicated by "+". Gill rakers were counted on the anterior gill arch. Valid species name was attributed according to Eschmeyer et al. 2018. Fish specimens were deposited as museum material in the Collection of İstanbul University, Faculty of Aquatic Sciences in $70 \%$ ethanol.

The samples were measured for standard length (SL) to the nearest $0.1 \mathrm{~cm}$ and weighed for total body weight (W) on a digital balance with a $0.01 \mathrm{~g}$ accuracy. The LWR was calculated using the equation: $\mathrm{W}=a \mathrm{~L}^{b}$, where $\mathrm{W}$ is the total weight ( $\mathrm{g}), \mathrm{L}$ is the standard length $(\mathrm{cm}), a$ and $b$ are regression parameters (Le Cren, 1951; Froese, 2006). The equation ( $\left.\mathrm{W}=a \mathrm{~L}^{b}\right)$ was converted into the natural logarithmic form $(\ln \mathrm{W}=\ln a+b \operatorname{lnSL}))$ and parameters $a$ (regression intercept) and $b$ (slope) were calculated by the regression analysis (King, 2007).

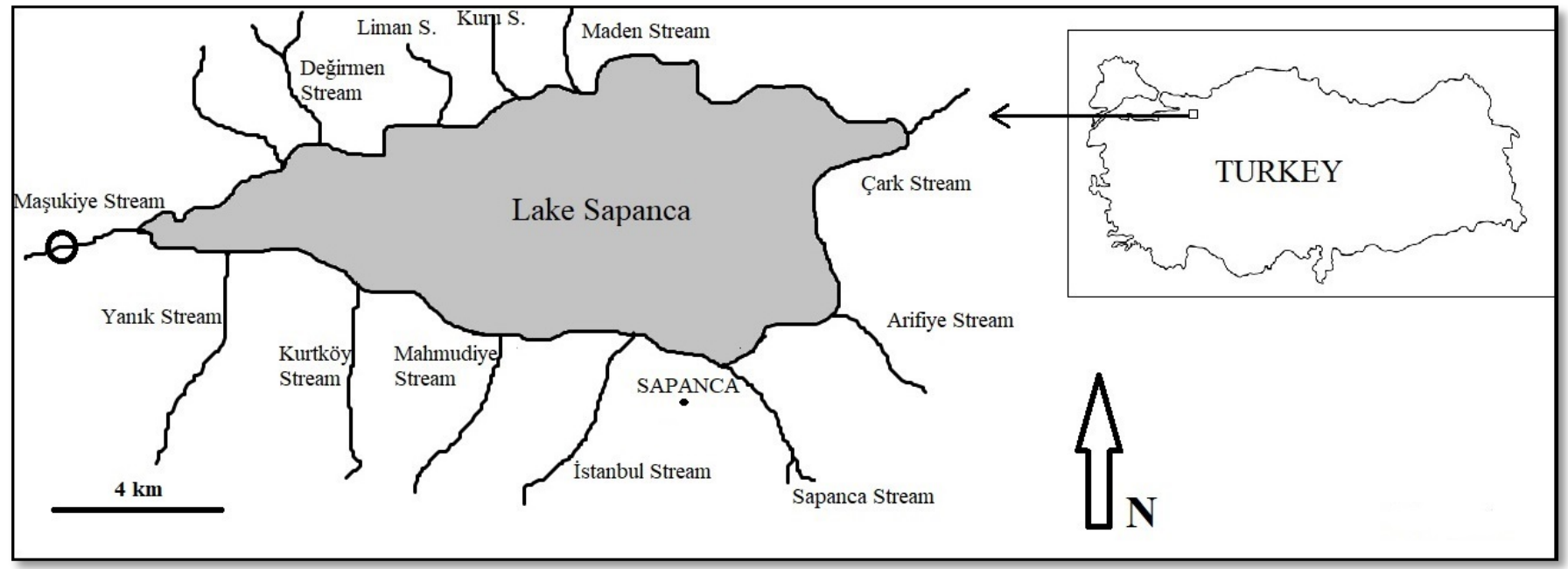

Figure 1. Sampling site (Maşukiye Stream) in the Lake Sapanca Basin. 


\section{Results and Discussion}

\section{Gobio sakaryaensis}

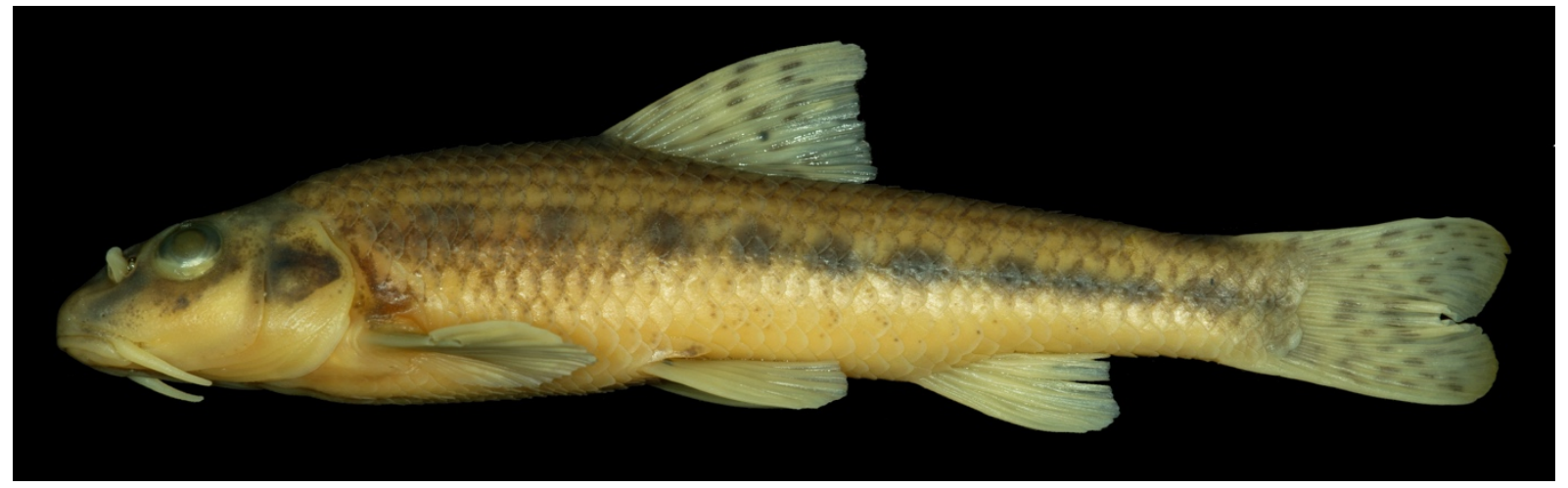

Figure 2. Gobio sakaryaensis, 59 mm SL; Turkey: Maşukiye Stream in the Lake Sapanca Basin

Materials examined: 17, 43-59 mm SL, Adapazar1 prov., Maşukiye Stream, tributary to the Lake Sapanca, Sakarya River drainage, $40.713970^{\circ} \mathrm{N} 30.131155^{\circ} \mathrm{E}, 05$ February 2009 - 1, 48 mm SL, Adapazarı prov., Maşukiye Stream, tributary to the Lake Sapanca, Sakarya River drainage, $40.713970^{\circ} \mathrm{N} 30.131155^{\circ} \mathrm{E}, 18$ October 2008 .

A total of 18 G. sakaryaensis specimens was caught from the Maşukiye Stream. Morphometric data of the species was given in Table 1.

Dorsal fin with 3 simple and $7 \frac{1}{2}-81 / 2$ branched rays. Anal fin with 3 simple and $6 \frac{1}{2}$ branched rays. Pectoral fin with $15-$ 16 rays. Pelvic fin with 8 rays. Lateral line complete, reaching to caudal-fin base, perforating 38-39 [(38(3), 39(7)] scales on body and 2 on caudal-fin base. Breast scaled completely. 6-8 scales between posterior extremity of pelvic-fin base and anus. 4-5 (mode 4) gill rakers. Pharyngeal teeth in two rows, 3.5-5.3, serrated, hooked at tip.

The length-weight relationship of the species was calculated and the sample size (n), length and weight ranges, parameters of the LWR equation ( $a$ and $b$ ) with $95 \%$ confidence intervals, $\mathrm{r}^{2}$ values were summarized in Table 2 .

Gobio sakaryaensis reported in this study has not previously been recorded from the Lake Sapanca Basin, and this finding has increased the number of the fish species living in the basin. It is thought that $G$. sakaryaensis, known to live in the Sakarya River Basin, may had come to the Sapanca Lake Basin with Çark Creek, which connects the Sakarya River to the lake. The occurrence of this species in the Lake Sapanca Basin shows that its distribution range has extended.
Not unexpected, there is a small difference in the morphometric of our materials (Table 1) and the data given by Turan et al. (2012): head length (\% 24.8 - 27.0 in our materials vs. $\% 27.2-30.0$ in Turan et al. (2012)), body depth at dorsal-fin origin ( $\% 19.3-21.3$ in our materials vs. $21.5-24.4$ in Turan et al. (2012)), predorsal length (\% $46.6-48.4$ in our materials vs. $\% 48.7-52.8$ in Turan et al. (2012)) and prepelvic length (\% $46.7-49.8$ in our materials vs. $\% 49.8$ -51.0 in Turan et al. (2012)). This difference is likely to be the result of differences in measuring fish, larger variations in fish sizes/numbers or seasonal variations.

The value of $b$ in the LWRs is expected to be ranged between 2.5 and 3.5 (Froese, 2006). In present study, the value of $b$ for $G$. sakaryaensis was within this range and, therefore the results can be used as valid. According to Innal and Erk'akan (2015), the $b$ value of G. sakaryaensis in Çamkoru Pond (Ankara, Turkey) was calculated 3.217. The differences in the $b$ values of the same species are possible affected by temporal and spatial variations due to different habitats, size range, sex, and season, gonad maturity, feeding habit and diseases, although these two estimated values of $b$ (3.217 for Çamkoru Pond population and 3.176 for Maşukiye Stream population) were similar. 
Table 1. Morphometric data of G. sakaryaensis caught from the Maşukiye Stream in the Lake Sapanca Basin $(\mathrm{n}=10)$.

\begin{tabular}{lcc}
\hline & Mean \pm SD & Min. - Max. \\
\hline Standard Length (SL, mm) & $49.68 \pm 4.53$ & $45.55-59.01$ \\
\hline in percent of $\boldsymbol{S L}$ & & \\
Head length & $25.81 \pm 0.68$ & $24.76-27.00$ \\
Body depth at dorsal-fin origin & $20.06 \pm 0.55$ & $19.31-21.25$ \\
Predorsal length & $47.58 \pm 0.51$ & $46.63-48.39$ \\
Prepelvik length & $48.55 \pm 1.06$ & $46.67-49.82$ \\
Preanal length & $70.33 \pm 1.35$ & $67.39-71.88$ \\
Depth of caudal peduncle & $9.86 \pm 0.19$ & $9.58-10.17$ \\
Length of caudal peduncle & $21.63 \pm 0.58$ & $20.98-22.57$ \\
\hline in percent of head length & & \\
\hline Head depth at eye & $63.28 \pm 1.09$ & $62.10-65.12$ \\
Head depth at nape & $51.92 \pm 1.35$ & $50.20-53.98$ \\
Snout length & $38.83 \pm 1.29$ & $36.70-40.45$ \\
Eye diameter & $28.28 \pm 1.29$ & $26.06-30.52$ \\
Interorbital width & $23.66 \pm 0.79$ & $22.53-24.82$ \\
\hline
\end{tabular}

Table 2. The descriptive statistics and estimated parameters of length-weight relationship of Gobio sakaryaensis in Maşukiye Stream (n: number of individuals, SL: standard length, W: body weight, Min: minimum, Max: maximum, $a$ : intercept, $b$ : slope, $95 \% \mathrm{CI}: 95 \%$ confidence limit, $\mathrm{r}^{2}$ : coefficient correlation).

\begin{tabular}{|c|c|c|c|c|c|c|c|c|}
\hline \multirow[t]{2}{*}{ Species } & \multirow[t]{2}{*}{$\mathbf{n}$} & SL, cm & $\mathbf{W}, \mathbf{g}$ & $\begin{array}{l}\text { Regression } \\
\text { rameters }\end{array}$ & Pa- & \multirow[t]{2}{*}{$95 \%$ CL of $a$} & \multirow[t]{2}{*}{$95 \%$ CL of $b$} & \multirow[t]{2}{*}{$\mathbf{r}^{2}$} \\
\hline & & Min.-Max. & Min.-Max. & $a$ & $b$ & & & \\
\hline G. sakaryaensis & 18 & $4.3-6.5$ & $1.266-4.093$ & 0.013 & 3.176 & $0.008-0.022$ & $2.857-3.495$ & 0.969 \\
\hline
\end{tabular}

\section{Comparative Material}

Gobio bulgaricus: IUSHM 35600-43, 5, 55-58 mm SL, Edirne: River Meriç, 23.08.2004, M. Özuluğ.

Gobio sakaryaensis: IUSHM 2019-1409, 2, 78-85 mm SL, Eskişehir: Stream about $37 \mathrm{~km}$ south of Bozüyük at road from Bozüyük to Kütahya, Sakarya drainage, 16.06.2006, M. Özuluğ, J. Freyhof.

\section{Conclusions}

Consequently, the present study has provided a new contribution to the fish fauna of Lake Sapanca Basin, and the first reference on LWR for G. sakaryaensis population in the area.

\section{Compliance with Ethical Standard}

Conflict of interests: The authors declare that for this article they have no actual, potential or perceived conflict of interests.

\section{References}

Albay, M., Akçaalan, R., Tüfekçi, H., Metcalf, S.J., Beattie, A.K, Codd, A.G., (2003). Depth profiles of cyanobacterial hepatotoxins (microcystins) in three Turkish freshwater lakes. $H y$ drobiologia, 505, 89-95.

Çiçek, E., Fricke, R., Sungur, S., Eagderi, E. (2018). Endemic freshwater fishes of Turkey. FishTaxa, 3(4), 1-39.

Ercan, E., Gaygusuz, Ö., Tarkan A. S., Reichard, M., Smith, C. (2013). The ecology of freshwater bivalves in the Lake Sapanca basin, Turkey. Turkish Journal of Zoology, 37, 730-738. 
Eschmeyer, W. N., Fricke, R., van der Laan, R. (eds), (2018), Catalog of Fishes: Genera, Species, References.

(http://researcharchive.calacademy.org/research/ ichthyology/catalog/fishcatmain.asp). Electronic version accessed 09 June 2018.

Froese, R. (2006). Cube law, condition factor and weight-length relationships: History, meta-analysis and recommendations. Journal of Applied Ichthyology, 22, 241-253.

Innal, D., Erk'akan, F. (2015), Length-weight relationship of Gobio sakaryaensis (Teleostei: Cyprinidae) from Camkoru Pond (Ankara-Turkey). International Journal of Fisheries and Aquatic Studies, 2(6), 424-426.

King, M. (2007). Fisheries Biology, Assessment and Management (2nd ed.). Blackwell Scientific Publications, Oxford, 1-381 pp. ISBN: 978-1-4051-58312

Kottelat, M., Freyhof, J. (2007), Handbook of European freshwater fishes. Berlin, $640 \mathrm{pp}$.

Le Cren, E.D. (1951). The length-weight relationship and seasonal cycle in gonad weight and condition in the perch (Perca fluviatilis). Journal of Animal Ecology, 20, 201-218.

Naseka, A. M., Erk'akan, F., Küçük, F. (2006), A description of two new species of the genus Gobio from Central Anatolia (Turkey) (Teleostei: Cyprinidae).

Zoosystematica Rossica, 15, 185-194.

Okgerman, H., Altuğ, G. (2008). Sapanca Gölü’ne Bilimsel Açıdan Bakış. TÜDAV Yayınları No:28.
Özuluğ, M., Tarkan, A.S., Gaygusuz, Ö., Gürsoy, Ç. (2007), Two new records for the fish fauna of Lake Sapanca Basin (Sakarya, Turkey). Journal of FisheriesSciences.com, 1(3), 152-159.

Tarkan, A. S., Özuluğ, M., Gaygusuz, Ö., Gürsoy Gaygusuz, Ç. (2007), A New Locality for the Freshwater Fish Chondrostoma angorense Elvira, 1987 (Osteichtyes: Cyprinidae) in the Marmara Region (Turkey). Ege University Journal of Fisheries \& Aquatic Sciences, 24(1-2), 165-166.

Tarkan, A.S., Gaygusuz, Ö., Özuluğ, M., Gürsoy Gaygusuz, Ç. (2008), Reoccurrence of Salmo trutta macrostigma (Duméril, 1858) in Lake Sapanca Basin (Sakarya, Turkey): implications for conservation. Journal of Fisheries and Aquatic Science, 3(1), 87-91.

Turan, D., Ekmekçi, F.G., Luskova, V., Mendel, J. (2012), Description of a new species of genus Gobio from Turkey (Teleostei: Cyprinidae). Zootaxa, 3257, 56-65.

Turan, D., Japoshvili, B., Aksu, İ., Bektaş, Y. (2016), Description of two new species of the genus Gobio (Teleostei: Cyprinidae) from the Black Sea coast of Turkey. Zoology in the Middle East, 62(2), 112-124.

Turan, D., Kaya, C., Bayçelebi, E., Aksu, İ., Bektaş, Y. (2017), Gobio baliki, a new gudgeon from Turkey (Teleostei: Cyprinidae). Zootaxa, 4350(2), 284-290.

Turan, D., Kaya, C., Bayçelebi, E., Aksu, İ., Bektaş, Y. (2018), Description of Gobio fahrettini, a new gudgeon from Lake Ilgin basin, Central Anatolia (Teleostei: Gobionidae). Ichthyological Exploration of Freshwaters, 28(4), 365-373. 